\title{
Architecture_MPS
}

\section{One Tool Amongst Many: Considering the Political Potential of Neighbourhood Planning for the Greater Carpenters Neighbourhood, London}

Cecil Sagoe ${ }^{1}$

How to cite: Sagoe, C. 'One Tool Amongst Many: Considering the Political Potential of Neighbourhood Planning for the Greater Carpenters Neighbourhood, London.' Architecture_MPS, 2016, 9(1): 3. DOI:

https://doi.org/10.14324/111.444.amps.2016v9i3.001.

Published: 01 May 2016

\section{Peer Review:}

This article has been peer reviewed through the journal's standard double blind peer-review, where both the reviewers and authors are anonymised during review.

\section{Copyright:}

(C) 2016, The Author(s). This is an Open Access article distributed under the terms of the Creative Commons Attribution License (CC-BY) 4.0 https://creativecommons.org/licenses/by/4.0/, which permits unrestricted use, distribution and reproduction in any medium, provided the original author and source are credited • DOI: https://doi.org/10.14324/111.444.amps.2016v9i3.001.

\section{Open Access:}

Architecture_MPS is a peer-reviewed open access journal. 


\section{Title: One Tool Amongst Many: Considering the Political Potential of Neighbourhood Planning for the Greater Carpenters Neighbourhood, London}

\section{Author: Cecil Sagoe}

\section{Architecture_media_politics_society. vol.9, no. 3.}

May 2016

Affiliation: University College London

\section{Abstract}

Currently within English planning literature there are polarizing debates about whether neighbourhood planning represents a politically useful tool for communities to utilize to challenge and shape top-down government development plans for their neighbourhood. One side of the debate optimistically presents neighbourhood planning as a radical and exciting opportunity for communities who wish to shape development plans for their locality. On the other side of the debate neighbourhood planning is denounced as a post-political governance technology which does not enable communities to meaningfully challenge and shape government development plans for their neighbourhood. This paper will engage with these competing perspectives whilst exploring how the Greater Carpenters Neighbourhood Forum (GCNF) are using neighbourhood planning to try and protect housing on the Carpenters Estate, a council estate in Stratford, east London.

This paper begins by providing a brief introduction to community participation in planning in England. Subsequently, this paper discusses benefits and challenges communities face engaging with formal planning mechanisms before specifically exploring perspectives on the challenges of using neighbourhood planning to realize their development aspirations for their neighbourhood. Drawing from interviews, planning document analysis, and ethnographic research carried out over the last year this paper then reflects on how neighbourhood planning is being deployed by 


\section{Amps}

the GCNF within a wider repertoire of community activities aimed at ensuring the protection and refurbishment of housing on the Carpenters Estate. Throughout this paper there will be reflection on whether participation in state planning processes represents a politically effective way for communities to shape development plans and outcomes for their neighbourhood. It will be argued that the political potential of neighbourhood planning for communities may be unlocked when it is pursued strategically in concert with a range of other actions aimed at challenging and shaping state development plans for a community's neighbourhood. 


\title{
Title: One Tool Amongst Many: Considering the Political Potential of Neighbourhood Planning for the Greater Carpenters Neighbourhood, London
}

\author{
Author: Cecil Sagoe
}

Architecture_media_politics_society. vol.9, no. 3.

May 2016

\section{Introduction}

The master's tools cannot dismantle the master's house, but perhaps when strategically used, they can allow those on the outside to occupy the master's house. ${ }^{1}$

On November 15, 2011 the English Localism Act was given Royal Assent. This Act was introduced by the Conservative Liberal-Democrat coalition government within a planning system that has long been regarded as hierarchical, offering few genuinely empowering spaces for communities to participate in the planning of their neighbourhoods. ${ }^{2}$ Ostensibly, this Act would redress this scalar-structural imbalance inscribed within the English planning system by providing "new rights direct to communities and individuals, making it easier for them to get things done and achieve their ambitions for the place where they live." 3 Arguably, the primary embodiment of these "new rights" is neighbourhood planning. Neighbourhood planning enables residents, workers, and business representatives within a neighbourhood to come together to produce a plan for their area once they have been formally constituted as a Neighbourhood Forum. This provision within the Localism Act "has been hailed as radical and exciting by some," whilst being seen as "fraught with risk and difficulties by others." 4

This paper will engage with these competing perspectives to help explore how the Greater Carpenters Neighbourhood Forum (GCNF) are using neighbourhood planning to assist them in ensuring the protection and refurbishment of housing on the Carpenters Estate, a council estate in Stratford, east London. Section 2 begins this exploration by providing a 


\section{Amps}

brief introduction to community participation in planning in Britain. It also outlines perspectives on benefits and challenges communities face engaging with formal planning mechanisms. Section 3 examines the potential benefits and difficulties for communities pursuing neighbourhood planning. Running through sections 2 and 3 will be an examination of whether participation in state planning processes is a politically effective way for communities to influence development plans and outcomes for their neighbourhood. ${ }^{5}$ Section 4 briefly outlines the case study and the methods used to gather data. Section 5 provides initial reflections on data collected. These reflections will discuss: (1) why the GCNF are using neighbourhood planning; (2) the way neighbourhood planning is being mobilized by the GCNF; and (3) whether the GCNF's mobilization of neighbourhood planning is a politically useful way for them to realize their housing aspirations for the Carpenters Estate. The paper concludes by highlighting further research avenues pertaining to neighbourhood planning.

\section{Participation in State Planning Processes: a Politically Useful Activity for Communities?}

In England communities have a rich history of engaging with planning strategies for their respective neighbourhoods and cities more broadly. "Community" is a highly contested term within the social sciences. Conventionally, community is "used merely as a synonym for 'the people who live in an area'. But the metaphor carries more meaning than this." ${ }^{\circ}$ People belong to a community not simply because they live in a similar place. People also belong to a community by virtue of sharing something in common with others, such as ethnicity, gender, sexual orientation, religious beliefs, and/or interests. Communities also form around institutions, such as parents of children attending an elementary school or people who work in the same office. ${ }^{7}$ Critically, communities are not static. Communities "are always changing as members join and leave and as connections to other communities grow or wither." 8 Thus, for this paper the term community captures the multi-faceted and dynamic ways in which diverse people interacting in a neighbourhood form bonds. ${ }^{9}$

Within England government debate about the desirability of community participation in state planning processes is commonly traced back to the Planning Advisory Groups' 1965 Report The Future of Development Plans. ${ }^{10}$ This report acted as a precursor to the establishment of the Skeffington Committee in 1968. This committee was tasked with considering and reporting on "the best methods, including publicity, of securing the participation of the public at the formative stage in the making of development plans or their area." 11 The Skeffington Report was published in 1969 and concluded that local development plans should be subject to full public scrutiny and debate. ${ }^{12}$ The recommendations of the report were not immediately taken up and have been criticized for only delineating limited ways for communities to participate in planning processes. ${ }^{13}$ However, over time the principles laid out in the 


\section{Amps}

report were incorporated into the English planning system. In fact since the late 1990s developers and local councils have been required to involve communities in producing development plans for their local area. The ostensible idea informing this requirement is that local communities have a better idea of their own local problems, and are therefore better equipped to identify solutions to these problems. ${ }^{14}$ As will be discussed later, some have questioned the purported benevolent intent informing this encouragement of community participation in state planning processes.

The actual benefits that communities derive from their participation in state planning processes has been a hotly debated topic within community planning literature. A central feature of these debates is whether participation in state planning processes represents a politically effective way for communities to try and shape development plans and outcomes for their neighbourhood. At this point it is useful to outline what is meant by "politically effective." Recently, critical planners have turned to Jacques Rancière to assist them in identifying what constitute politically effective activities for communities. ${ }^{15}$ Rancière's understanding of politically effective activities is based on his conceptions of "politics" and "the political." For Rancière, politics should not be identified as the exercise of, and struggle to possess, power, as to do so "is to do away with politics." 16 Rather, politics should be regarded as activities which question and disrupt existing elite governance orders. ${ }^{17}$ For Rancière then "the political" is the moment of politics; it is that moment which "makes visible what had no business being seen, and makes heard a discourse where once there was only place for noise; it makes understood as discourse what was once only heard as noise." 18

Rancière's conception of politics is problematic. It vastly underplays the important connection between the exercise of, and the struggle to possess, power and the realization of disruptive political moments. For example, genuine community empowerment - that is, enhancing the power of communities "to make choices and to transform those choices into desired actions and outcomes"19 - can equip communities with necessary tools to question and disrupt existing political orders. The work of politics scholar Chantal Mouffe, whose oeuvre is concerned with critically conceptualizing politics, is useful here. Mouffe helps us to understand why power should be regarded as a constitutive element of "politics" and thus "the political." She notes that any political order is brought into being through sets of practices and institutions, ${ }^{20}$ and at their heart political orders reflect an "expression of a particular structure of power relations." ${ }^{21}$ Consequently, these orders cannot be disrupted "without challenging existing power relations." 22 From this standpoint, it can be argued that any conceptualization of politics should acknowledge the importance of the exercise of, and the struggle to possess, power in leading to the realization of political moments. The exercise of and struggles to possess power are in fact central components of politics. Mouffe's conceptualization of politics informs this paper's understanding of what activities are regarded as politically effective for communities to engage with. 


\section{Amps}

When considering whether participating in state planning processes provides a politically effective way for communities to shape development plans for their neighbourhood, a more positive outlook can be found amongst scholars within the collaborative planning discourse. Broadly speaking, collaborative planning advocates all stakeholders within a locality participating in the production of development plans for that area. In particular, collaborative planners place a strong normative emphasis on ensuring community-level actors play a role in shaping development plans for their neighbourhood, alongside state and market actors. ${ }^{23}$ Generally, advocates of collaborative planning optimistically assume that communities have the power to realize their development aspirations for their neighbourhood through participating in the plan-making process for their area. ${ }^{24}$ There is a belief that collaborative planning empowers communities to directly articulate their aspirations for their neighbourhood to state planners.

Collaborative planners correctly acknowledge that communities can theoretically articulate their aspirations for their neighbourhood to state planners through participating in planning processes. Generally, however, collaborative planners also naively and worryingly omit discussion of the effect of power in determining whose voice $(s)$ or which interests carry weight within the plan-making process. One prominent advocate of collaborative planning who does not shy away from this critical discussion is Patsy Healey. Healey acknowledges that difficulties arise in assimilating a plurality of wide-ranging perspectives into a unified approach. Notably, she highlights that collaborative planning has the potential to "be a force for ideological domination" whereby a diversity of community concerns and visions for their local area are considered but then crowded out by "key" national and city-wide strategic and financial concerns. ${ }^{25}$ Fundamentally, Healey recognizes that neighbourhood communities are not automatically empowered in collaborative planning spaces to shape the direction of government plans for their neighbourhood. Informing this salient critique is a recognition that existing unequal power relations between the plurality of state, market, and community actors in a particular locality can be replicated within collaborative planning spaces.

Concerns about the aforementioned issues as well as the perceived malevolent intent behind collaborative planning processes enacted by state actors has informed stinging critiques of these processes. Critiques have come from a variety of perspectives and frameworks. ${ }^{26}$ However, over recent years the most strident critiques have come from those adopting arguments made within the post-political discourse. ${ }^{27}$ The post-political discourse is founded on Jacques Rancière's conception of politics (previously outlined) - activities which question and disrupt elite governance orders. Consequently, scholars within the post-political discourse conceptualize post-politics as activities that further consolidate rather than challenge existing governance orders. ${ }^{28}$ Broadly speaking these scholars have expressed concerns that within a neoliberal era we are experiencing a post-political condition. 


\section{Amps}

This condition is marked by the replacement of "debate, disagreement and dissensus with a series of technologies of governing that fuse around consensus, agreement, accountancy metrics and technocratic environmental management." 29

Planning scholars who draw from the post-political discourse regard state planning frameworks to be one of these post-political governance technologies/tools. Thus, for these scholars, community participation in state planning processes is not a political activity. ${ }^{30}$ For these scholars community engagement with state planning programmes does not enable communities to disrupt the ideological visions informing these programmes, unlike more radical activities such as protest movements and nonconformist modes of intervention. Rather, encouraging community participation in actuality represents a manipulating governance technique, generating community "acquiescence" for predetermined top-down plans for the locality in question. ${ }^{31}$ Acquiescence is achieved, for instance, by governments demarcating only very limited ways for communities to participate in these spaces. ${ }^{32}$ It is perhaps a mistake to suggest that there is total community acquiescence within these planning spaces. When participating in state planning processes community groups do object, indeed quite vociferously, to strategic plans for their locality. ${ }^{33}$ However, the more fundamental point this post-political critique is making is that community participation in state planning processes is not designed benevolently to enable communities to shape planning outcomes in their own vision(s). Rather, it is designed to gain informal community consent over predetermined top-down planning agendas.

This post-political critique certainly identifies important issues arising from community participation in state planning programmes. But this critique also, problematically, fails to consider how communities may mobilize their participation in state planning processes in politically useful ways for them. This failing arises from the limited conception of politics upon which the post-political discourse is founded; one which suggests that politics is not about the exercise of, or struggle to possess, power. Adopting this limited conception of politics forecloses the opportunity to consider situations in which communities display agency in mobilizing their participation in state planning in empowering ways. This is not to say that every instance of community participation in state planning processes should be regarded as political. Adopting this argument puts one in danger of overemphasizing the benefits communities (who wish to shape city planning outcomes) can currently derive from only participating in state planning. Rather, what is being argued is the avoidance of immediately denouncing all instances of community participation in state planning as post-political. Instead it may be a more productive exercise to consider the context in which community participation in state planning is taking place. Through adopting this approach, the door is opened to serious examinations of situations in which communities are mobilizing their participation in state planning processes in potentially political ways. 


\section{Amps}

\section{Considering the Political Potential of Neighbourhood Planning for Local Communities}

A central concern of this paper is considering whether neighbourhood planning can be mobilized politically by communities to assist them in realizing their housing aspirations for their neighbourhood. Debates about the political usefulness of neighbourhood planning mirror broader discussions about the benefit to communities of participating in state planning processes. As highlighted in the introduction, there are those who hail neighbourhood planning as "radical and exciting." 34 Proponents of neighbourhood planning believe that constituted Neighbourhood Forums are provided with "direct power to develop a shared vision for their neighbourhood and shape the development and growth of their local area." 35 Neighbourhood planning is therefore conceptualized as providing communities with "a powerful set of tools"; tools that enable them to occupy a key space within the state planning system to "get the right types of development in the right place" for their locality. ${ }^{36}$ Neighbourhood planning may therefore initially represent a powerful devolution of planning responsibilities to neighbourhoods, empowering them to achieve positive planning outcomes for their communities. ${ }^{37}$

Critics of neighbourhood planning, however, are less than sanguine about neighbourhood planning's potential to benefit communities. Critics keenly stress that neighbourhood planning does "not necessarily give communities greater leverage over the principal changes that they are most concerned about," 38 such as challenging plans for more housing within their neighbourhood. Neighbourhood Forums must ensure that their plans are in "general conformity" with state plans drawn up at higher strategic scales ${ }^{39}$ Often these are plans which communities had a limited part in formulating. Therefore policies and visions within the plans may be incongruent with community aspirations for their neighbourhood. Critics argue that requiring adherence to this scalar-structural constraint means that existing power relationships between community groups and policy actors are not transformed in neighbourhood planning spaces. ${ }^{40}$ Additionally, they argue that this constraint prevents communities from using neighbourhood planning to question and transform the central, metropolitan, and local government visions informing development plans for their neighbourhood. ${ }^{41}$ Instead, they can only deliberate on the finer details of these development plans for their area, a mechanism which gains informal community consent for the development plans' broader goals.

Paying attention to these post-political style critiques of neighbourhood planning are vital. They highlight significant scalar-structural constraints imposed on neighbourhood planning, limiting the efficacy of certain types of community engagement with this planning programme. For instance, questions are raised about the ability of communities to use neighbourhood planning to stem the tide of oncoming property-led regeneration, facilitated by their local authority's own plans, which may lead to their displacement. In 


\section{Amps}

light of these critiques it is tempting to suggest that neighbourhood planning does not represent a politically effective planning tool for communities to use. Adopting this perspective is especially alluring in circumstances where communities are hoping to put forward alternative development plans to those drawn up by their local authority.

Adopting this perspective, however, is unhelpful in explaining why numerous communities are engaging with neighbourhood planning despite being cognizant of its scalar-structural constraints (Figure 1). Rather than outright derision of community engagement with neighbourhood planning it is more pertinent to ask why, in the face of the constraints within which neighbourhood planning operates, are neighbourhoods still actively engaging with it? In what ways or in what circumstances is neighbourhood planning playing a politically useful role for these communities? The broader conception of politics outlined in section 2 is helpful when addressing these salient questions as it directs academic inquiry towards exploring potentially empowering ways in which communities employ neighbourhood planning. Using Mouffe's conception of politics presented in section 2, this paper now seeks to address the questions outlined above through reflections on the GCNF's activities.

\section{Case Study and Methodology}

This case study reflects on the early stages of the GCNF's pursuit of neighbourhood planning as a tool which can assist them in achieving their aim to protect and ensure the refurbishment of the existing housing stock on the Carpenters Estate (amongst other things). Through this reflection this paper hopes to outline how neighbourhood planning can be politically mobilized by communities.

The GCNF was formed in July 2014 and was officially designated as a Neighbourhood Forum on July 21, 2015. Currently there are 106 Forum members. These members comprise residents, non-resident leaseholders, and workers within the Greater Carpenters Neighbourhood (GCN). The GCNF was set up with the express purpose of furthering the social, economic, and environmental well-being of the GCN. The GCN (Figure 2) falls within the planning boundary of the London Legacy Development Corporation (LLDC) (Figure 3) - a Mayoral Development Corporation which acts as the GNCF's local planning authority. Newham Council was previously the local planning authority for the GCN until the LLDC took over planning powers from Newham in 2012 as part of the LLDC's wider remit to plan for urban development within London's Olympic Park and its peripheries post-London 2012. The GCN is crucially home to the Carpenters Estate, a council estate that forum members are attempting to protect. The estate was completed in its current form in the late 1960s and comprises about 700 housing units. It is a council estate which has long been touted for redevelopment. ${ }^{42}$ 


\section{Amps}

The case study material for this research is drawn from wider research for a doctoral thesis. Data have been drawn from several sources. First, interviews were conducted with several GCNF members. These interviews tried discern why the GCNF was established and to gather perspectives on the intended role neighbourhood planning will play in assisting the GCNF to protect and ensure the refurbishment of housing within the Carpenters Estate. Secondly, data have come from ethnographic observations of meetings and planning consultations (from July 2014 to September 2015) that GCNF members have organized or participated in. This ethnographic research has attempted to gain insights into how the pursuit of neighbourhood planning is working in concert with other activities with which the GCNF engages, which are geared towards protecting and refurbishing housing on the Carpenters Estate. Relevant planning documents and legislation have also been analysed to ascertain what powers neighbourhood planning legally provides to Neighbourhood Forums. In this regard interviews were conducted with two civil servants within the Department for Communities and Local Government (DCLG) and an LLDC planning officer. What follows presents the author's initial reflections on the data gathered.
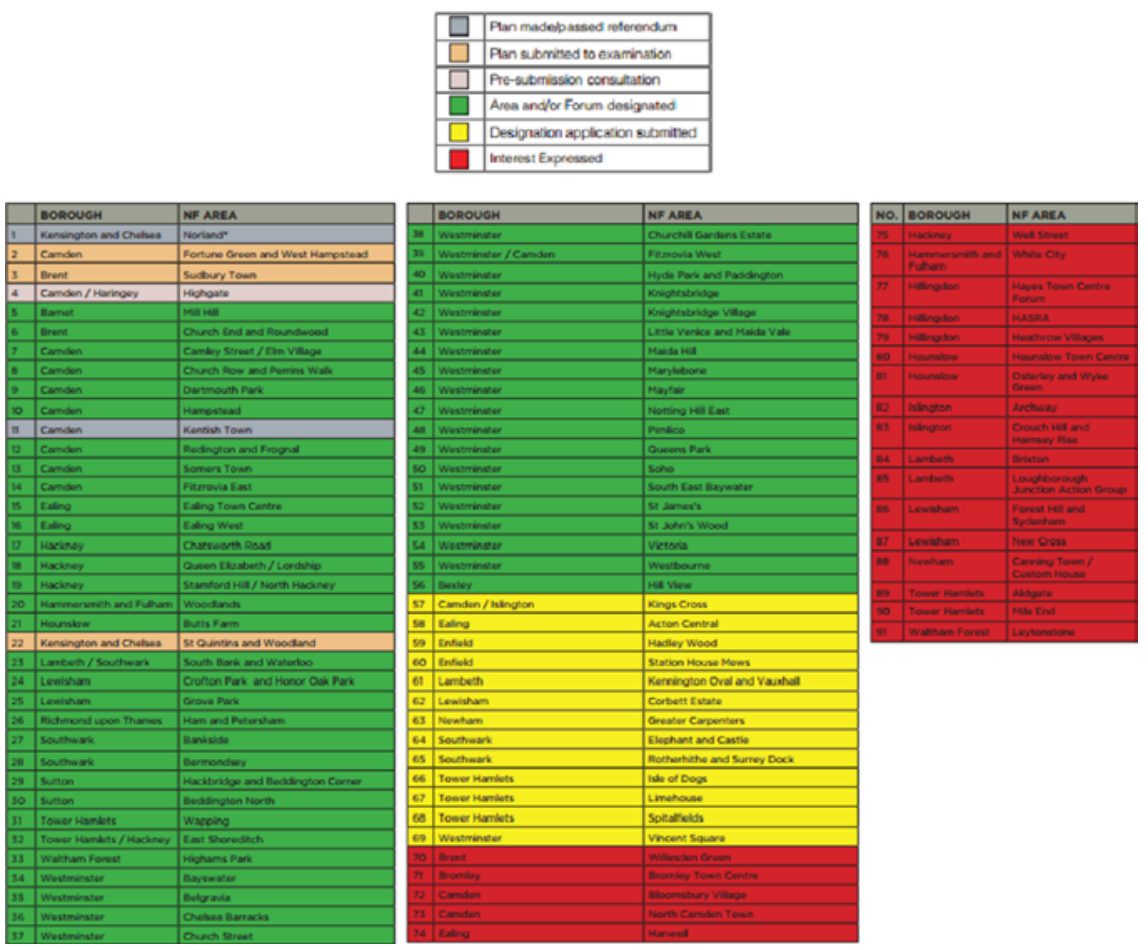

Figure 1. London Neighbourhood Forums, June 2015 (London

Communications Agency) 


\section{Amps}

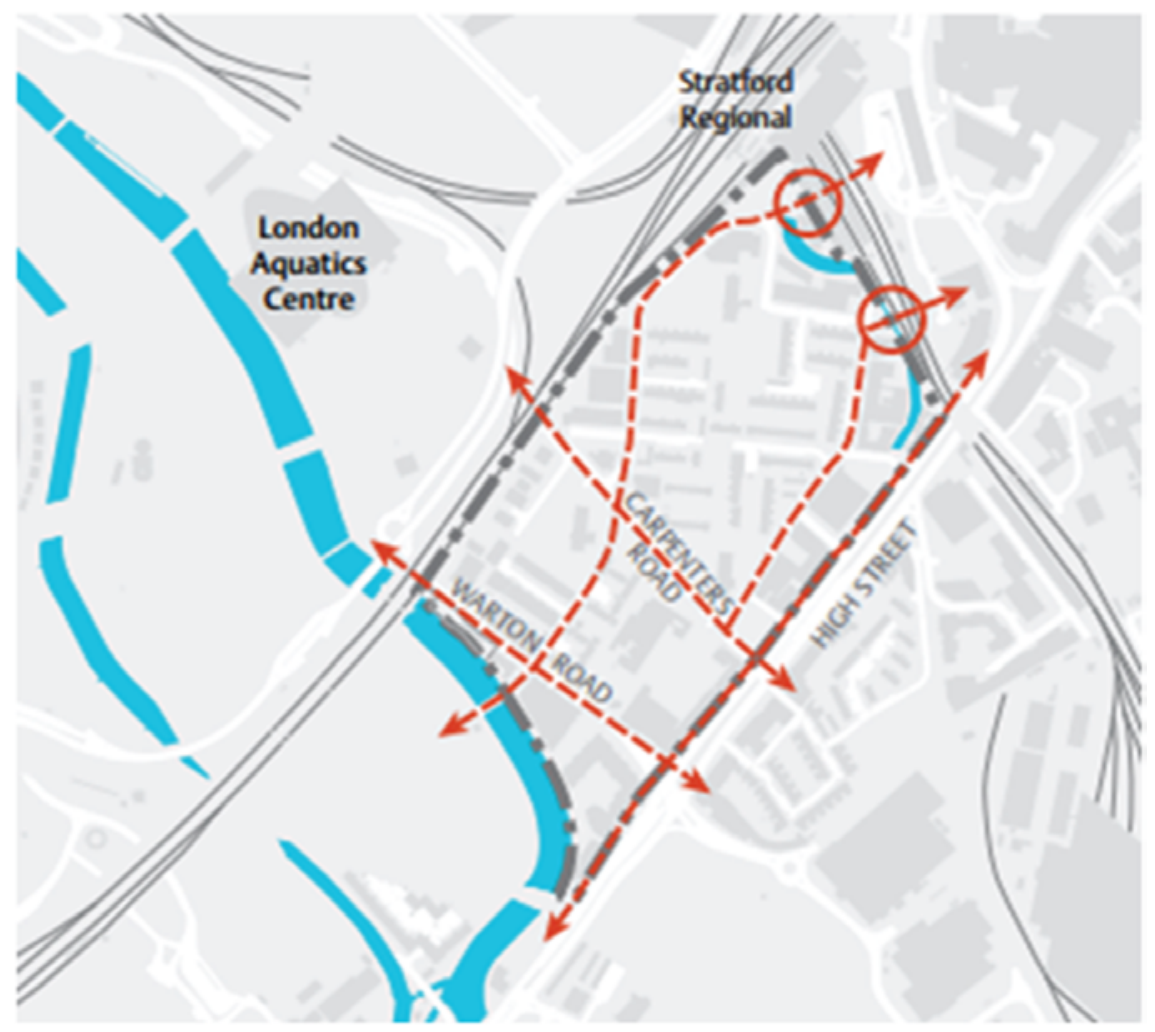

Figure 2. Greater Carpenters Neighbourhood (LLDC, Local Plan 2015 to 2031 (2015), 200)

\section{Reflections on Genf's Early Pursuit of Neighbourhood Planning}

In July 2014 the first meeting of the GCNF was held at the Building Crafts College within the Carpenters Estate. This meeting was relatively well attended with just over thirty people present. In attendance were a variety of residential interests (freeholders, leaseholders, and tenants), business interests, and individuals who are attempting to support the GCNF throughout the neighbourhood planning process; this composition of attendees highlights that the GCN community is broader than just the people residing in the neighbourhood. There was a conspicuous racial and ethnic diversity amongst those in attendance, a microcosm of Newham's racial and ethnic diversity. ${ }^{43}$ This diversity was a welcome sight, considering that some community planning literature recognizes that ethnic minorities are often marginalized from planning processes in England. ${ }^{44}$

There was a modest buzz in the air as people keenly awaited hearing what use neighbourhood planning might be for the GCNF. One Forum member 


\section{Amps}

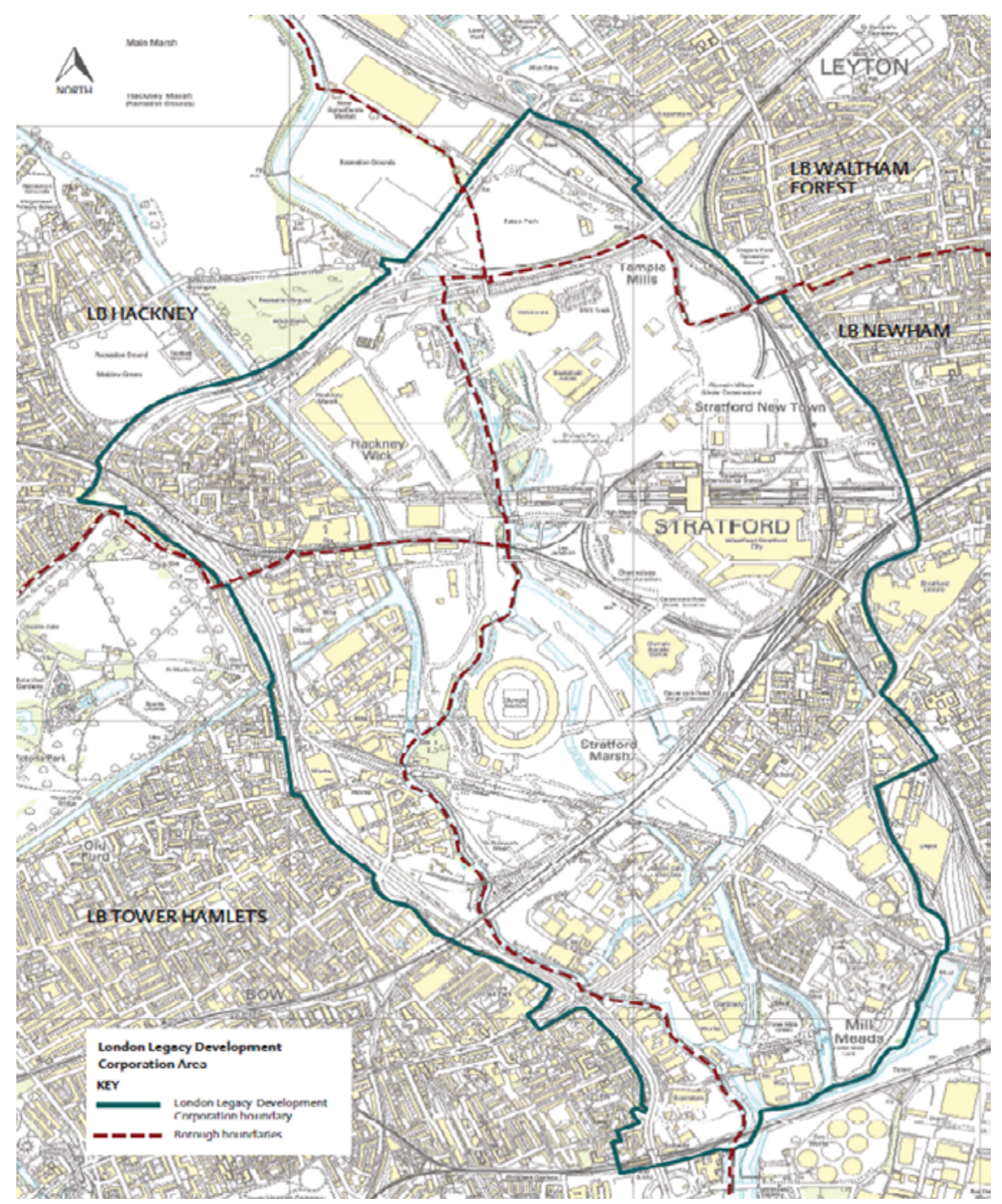

Figure 3. LLDC's Planning Boundary: "Planning Area Map," 2015

(who is also a Carpenters Estate resident) who was facilitating the meeting duly obliged at the start of the session:

I think we should make a Forum because over the years we've had lots and lots of master planners come and go and tell us what they think their vision of what the area could be. And I think that this is an excellent opportunity for us, ourselves, to say what we think of our estate, what our vision of our estate is, and to be actually involved in the planning process of it. So 


\section{Amps}

that's why I think that we should all embrace the thought of a Neighbourhood Plan.

Interviewed GCNF members expressed similar sentiments when asked what use they thought neighbourhood planning would be:

It can bring people together. It can encourage people to be involved in their own futures and their own destiny ... it's also a way of actually giving people a proper say in the shape of their community in the future, within, I think generally sensible guidelines.

[T] he plan itself is to outline our aim, as a Neighbourhood, to map out if you like who is a part of that, and geographically where it fits; to recognize that we do want to retain social housing and within that there is a mixed sort of development ... So what we're talking about is we recognize the need to keep a mixed tenure group - tenants, leaseholders, etc., - alongside sort of a mixed sort of affordability scale. So social housing, some private rented, etc.

These sentiments express an intention to use neighbourhood planning as a tool empowering members to vocalize their vision for the Carpenters Estate, be involved in planning decisions around it, and to ideally ensure the retention of existing social housing. This pursuit of neighbourhood planning is couched within a long history of estate activism geared towards protecting the estate's existing housing stock. This activism has encompassed a broad range of different activities. As interviews revealed, some broader historical activism on the estate included: setting up a campaign group called Carpenters Against Regeneration Plans, ${ }^{45}$ lobbying local government, media campaigns, letter writing, participation in planning consultations, and producing a community plan. Pursuing all these activities suggests a recognition amongst active GCNF members that a diversity of activities, mechanisms, and tools should be utilised when seeking to resist state regeneration plans for their neighbourhood. Indeed, all of these activities - along with a highprofile two-week occupation of the Carpenters Estate by a campaign group called Focus E15 mothers ${ }^{46}$ - have in their own way been useful tools in helping resist the estate's wholesale demolition. The breakdown of proposals for University College London to turn the Carpenters Estate into a university campus, largely for commercial reasons, has also meant that the estate has not undergone redevelopment. ${ }^{47}$ Sadly, despite these varied activities and developments, a lengthy and virulent decanting process has still left nearly 400 homes on the estate lying empty.

So why the turn to neighbourhood planning? In what ways is it a politically useful governance tool for the GCNF to ensure the protection and refurbishment of homes on the estate, especially as their Neighbourhood Plan must be congruent with the strategic planning policies set out within the Local Plan for their area? Discussions with a policy adviser from the decentralization and neighbourhood planning team within the DCLG highlighted that 


\section{Amps}

this neighbourhood planning rule has been a source of frustration for many Forums in England:

It can be frustrating for groups who don't agree with what the Local Plan is saying as written by the local authority [and] who disagree with how many houses there should be, or whatever it might be with those kind of strategic level questions.

This frustration arises as, under current rules, attempts by Neighbourhood Forums to use neighbourhood planning to challenge local authority redevelopment plans for their locality "get very short shrift" 48 under current rules. In other words, neighbourhood planning alone is unlikely to empower Forums to challenge and alter redevelopment plans for their neighbourhood; in neighbourhoods containing social housing, local authority redevelopment plans for these areas consistently cause significant social housing losses. ${ }^{49}$ In light of the reality that the LLDC's Local Plan seeks "extensive mixed-use redevelopment" within the GCN,,$^{50}$ concerns begin to arise about the political usefulness of neighbourhood planning in helping the GCNF to protect and ensure the refurbishment of social housing within the Carpenters Estate. When these concerns were raised in interviews, GCNF members, after highlighting they were keenly aware of the rules attached to neighbourhood planning, provided intriguing responses. These responses indicated how they may be able to mobilize neighbourhood planning politically. One GCNF member noted that neighbourhood planning is just "one of the routes" they are pursuing. Substantiating this point another GCNF member stated:

[B]eyond what we're doing in terms of the Neighbourhood Plan and the Neighbourhood Forum is to make sure that we also speak to those in planning, i.e. through [the] Local Plan, through the Examination in Public, through any of the Council's cabinet meetings that they have to ratify how they go forward.

Emerging from these statements is a recognition that neighbourhood planning is just one of many tools, avenues, or processes that the GCNF currently have at their disposal to prevent the redevelopment of social housing on their estates. Additionally, there is an acknowledgement that neighbourhood planning needs to be pursed alongside a number of activities specifically geared towards shaping and altering state plans for the GCN. This is a strategy that has already brought some gains for the GCNF in ways which may unlock some of neighbourhood planning's political potential. For example, after extensive and antagonistic involvement in the consultation of the LLDC's Local Draft Plan, GCNF members (and individuals supporting them) pressured the LLDC into amending some development principles in their housing strategy. Notably, the LLDC have included in their Local Plan the principle that "[p]rotecting existing residential stock is also a key component" of their overall housing strategy. The LLDC have also highlighted that the [1]oss of residential units, including 


\section{Amps}

affordable housing, floorspace or land will be resisted."51 These provisions are congruent with the GCNF's own stance on this issue. Thus there exists a basis for the GCNF to develop policies within their Neighbourhood Plan which seek the retention and the refurbishment of existing housing within their neighbourhood. As adopted Neighbourhood Plans become statutory planning documents, any planning application for development within the GCN would then have to adhere to these policies (in theory at least).

This example points towards one central way in which neighbourhood planning can potentially be mobilized politically by communities: by pursuing neighbourhood planning alongside other methods which pressure local authorities into making their housing plans congruent with community housing visions for their neighbourhood. A better platform is then provided for communities to develop Neighbourhood Plans that are simultaneously in general conformity with their local authority's housing strategies and reflect diverse community housing aspirations. This conclusion does not mean that there should be an uncritical uptake of neighbourhood planning within England. Rather, it is a call for careful consideration, on a context by context basis, of what politically useful role neighbourhood planning can play for communities, as part of a broader multi-faceted strategy. Of course in many cases communities may see no political value in neighbourhood planning, particularly when their aspirations for their neighbourhood conflict with their local authority's development plans for their area. In the case discussed here it initially appears to have been useful for the GCNF to pursue neighbourhood planning alongside and after pressuring the LLDC through other channels to amend the housing development principles within their Local Plan.

Pressuring local authorities into altering housing strategies for a neighbourhood (shaped at national and metropolitan scales) is of course no easy feat. Broader strategic and financial interests informing redevelopment processes amplify this difficulty. ${ }^{52}$ Notably for the GCN the LLDC's Local Plan highlights that they will only consider retaining existing housing within the GCN "where this does not prevent the achievement of wider regeneration objectives." 53 This is despite the existence of the aforementioned development principles laid out in the LLDC's Local Plan which will ostensibly protect the Estate's existing housing stock from demolition. Consequently, within the GCN some Forum members hold valid concerns that wider government and developer interests in their neighbourhood may still facilitate the demolition and loss of the existing housing stock on the Carpenters Estate. In the face of continued government and developer interests in redeveloping the Carpenters Estate it will be intriguing to observe what other tools (lying both within and outside of planning) the GCNF adopt to try and protect the estate's existing housing stock. It will be particularly important to pay attention to the shifting role(s) that neighbourhood planning plays as one tool amongst many to assist the GCNF in realizing their aspirations for their neighbourhood. Observing these shifts will be helpful in assessing the changing political usefulness of neighbourhood planning for the GCNF. 


\section{Amps}

\section{Conclusion}

This paper sought to investigate what political use neighbourhood planning has in assisting communities to realize their housing aspirations for their neighbourhood. The paper acknowledges that communities certainly face profound challenges in successfully using planning to challenge development plans for their locality. Additionally, this paper expressed serious reservations about whether England's planning system is benevolently designed by the government to allow communities to challenge top-down state plans for their neighbourhood. Despite these reservations, this paper has rejected the a priori dismissal of neighbourhood planning, and more broadly community participation in planning, as always "post-political." Instead, it has argued that it is more productive to consider contexts in which neighbourhood planning may or may not be a politically useful programme for communities to engage with. Reflecting on the GCNF's attempts to ensure the protection and refurbishment of existing housing within the Carpenters Estate, this paper highlighted one central way in which neighbourhood planning's political potential could be unlocked: through pursuing neighbourhood planning in concert with a range of other activities that successfully pressure the state (at a variety of scales) into altering their development plans for a neighbourhood.

This argument has been developed in relation to only one case study and at a time when the neighbourhood planning programme in England is only in its early years. It will be important for future neighbourhood planning research to build up a portfolio of cases documenting the varying experiences of Neighbourhood Forums that attempt to use neighbourhood planning to "occupy" a key space within the government's planning "house." Particularly pertinent will be exploring how Neighbourhood Forums are deploying neighbourhood planning, as part of a wider repertoire of action, to realize their development aspirations for their respective neighbourhoods. It will be intriguing to explore how planning authorities deal with Neighbourhood Forums that use a variety of tools to shape development plans for their neighbourhood. In this regard it will be crucial to explore conditions under which Neighbourhood Forums successfully complement their "occupation" of planning space with other measures to empower them to challenge and provide alternatives to top-down state development plans for their neighbourhood. Equally important is identifying reasons why Neighbourhood Forums are unsuccessful in their attempts at challenging and providing alternatives to top-down plans for their neighbourhood. Building this portfolio of cases may importantly provide the post-political discourse with greater contextual detail of situations in which neighbourhood planning may or may not be conceptualized as post-political. In particular these cases will be instructive in enhancing understandings of the political worth of neighbourhood planning as part of a multi-faceted social action strategy aimed at challenging and altering top-down development plans for neighbourhoods. 


\section{Amps}

\section{Notes}

1 Ananya Roy, "Urban Informality: Toward an Epistemology of Planning," Journal of the American Planning Association 71(2) (2005): 155.

2 Graham Haughton and Philip Allmendinger, "Moving On - From Spatial Planning to Localism and Beyond," Town and Country Planning 80(4) (2011): 186.

3 Department for Communities and Local Government (DCLG), "A Plain English Guide to the Localism Act” (2011), 8, accessed February 11, 2015, https://www. gov.uk/government/uploads/system/uploads/attachment_data/file/5959/1896534. pdf.

4 Gavin Parker, "Neighbourhood Planning: Precursors, Lessons and Prospects" (paper presented at the 40th Joint Planning Law Conference, Oxford, September 14-16, 2012), 2.

5 Section 2 will outline what this paper understands by the term "politically effective."

6 Patsy Healey, Collaborative Planning: Shaping Places in Fragmented Societies, 2nd edition (Basingstoke: Palgrave, Macmillan, 2006), 123.

7 William Peterman, Neighbourhood Planning and Community-Based Development: The Potential and Limits of Grassroots Action (Thousand Oaks, CA: SAGE, 2000), 21-2.

8 Ibid, 22.

9 Catherine Durose and Vivien Lowndes, "Neighbourhood Governance: Contested Rationales within a Multi-Level Setting - A Study of Manchester," Local Government Studies, 36(3) (2010): 343.

10 Planning Advisory Group, The Future of Development Plans, Report of the Planning Advisory Group (PAG) (London: HMSO, 1965).

11 Council on Tribunals, Public Participation in Planning - The Skeffington Report: "People and Planning" (1969). BL 7/9, The National Archives, London.

12 Ministry of Housing and Local Government, People and Planning: Report of the Committee on Public Participation in Planning (1969), 77. CAB 151/65, The National Archives, London.

13 Seán Damer and Cliff Hague, "Public Participation in Planning: A Review," The Town Planning Review 42(3) (1971): 226.

14 See the following for notable planning programmes that have adopted this ethos: John Pratt and Rebecca Fearnley "Stratford City Challenge," in Rising East: the Regeneration of East London, ed. Tim Butler and Michael Rustin (London: Lawrence \& Wishart, 1996), 327-52. Mark Tewdwr-Jones, Janice Morphet, and Philip Allmendinger, "The Contested Strategies of Local Governance: Community Strategies, Development Plans, and Local Government Modernisation," Environment and Planning A 38(3) (2006): 534. Mike Raco, Gavin Parker, and Joe Doak, "Reshaping Spaces of Local Governance? Community Strategies and the Modernisation of Local Government in England," Environment and Planning C: Government and Policy 2(4) (2006): 477.

15 Mike Raco and Wen-I Lin, "Urban Sustainability, Conflict Management, and the Geographies of Postpoliticism: A Case Study of Taipei," Environment and 


\section{Amps}

Planning C: Government and Policy 30(2) (2012). Phil Allmendinger and Graham Haughton, "Post-Political Spatial Planning in England: A Crisis of Consensus?," Transactions of the Institute of British Geographers 37(1) (2012).

16 Jacques Rancière, "Ten Theses on Politics," Theory and Event 5(3) (2001), accessed September 24, 2014, http://muse.jhu.edu/journals/theory_and_event/ v005/5.3ranciere.html.

17 Ibid.

18 Jacques Rancière, Disagreement: Politics and Philosophy (Minneapolis, MN: University of Minnesota Press), 30.

19 Nick Gallent and Steve Robinson, Neighbourhood Planning: Communities, Networks and Governance (Bristol: Policy Press, 2012), 72.

20 Chantal Mouffe, On the Political: Thinking in Action (London and New York: Routledge, 2005), 9.

21 Ibid. 18.

22 Ibid. 51.

23 Healey, Collaborative Planning.

24 Gallent and Robinson, Neighbourhood Planning, 70.

25 Healey, Collaborative Planning, 311.

26 Sue Brownill and Gavin Parker, "Why Bother with Good Works? The Relevance of Public Participation(s) in Planning in a Post-Collaborative Era," Planning Practice and Research 25(3) (2010): 275-82. Bill Cooke and Uma Kothari, "The Case for Participation as Tyranny," in Participation the New Tyranny, ed. Bill Cooke and Uma Kothari (London and New York, Zed Books, 2001), 1-15.

27 Phil Allmendinger and Graham Haughton, "Post-Political Regimes in English Planning: From Third Way to Big Society," in Planning Against the Political: Democratic Deficits in European Territorial Governance, ed. Jonathan Metzger, Phil Allmendinger, and Stijn Oosterlynck (Abingdon: Routledge, 2015), 44-7.

28 Erik Swyngedouw "The Antinomies of the Postpolitical City: In Search of a Democratic Politics of Environmental Production," International Journal of Urban and Regional Research 33(3) (2009): 609.

29 Ibid. 604.

30 Allmendinger and Haughton, "Post-Political Spatial Planning in England."

31 Ibid. 93.

32 See Greater London Authority, "Draft Further Alterations to the London Plan: The Spatial Development Strategy for Greater London” (2014), 2, accessed July 1, 2014, https://www.london.gov.uk/sites/default/files/FALP.pdf.

33 See London Legacy Development Corporation, "Local Plan Publication Stage Archive" (2015), accessed February 15, 2015, http://queenelizabetholympicpark. co.uk/our-story/transforming-east-london/local-plan/local-plan-publicationstage-archive. Contains a collection of critical comments that community representatives have provided to the LLDC during the consultation for the production of their Local Plan.

34 Parker, Neighbourhood Planning, 2.

35 DCLG, "Plain English Guide to the Planning System" (2015): 11, accessed February 


\section{Amps}

11, 2015, https://www.gov.uk/government/publications/plain-english-guide-to-theplanning-system.

36 Locality, "The Power of Neighbourhood Planning" (2014), accessed February 10, 2015, http://mycommunityrights.org.uk/wp-content/uploads/2014/12/The-Powerof-NP1.pdf.

37 Gallent and Robinson, Neighbourhood Planning, 27.

38 Ibid. 160.

39 DCLG, "Plain English Guide," 12.

40 Gallent and Robinson, Neighbourhood Planning, 176.

41 Parker, Neighbourhood Planning, 4.

42 Paul Watt, “'It's not for us': Regeneration, the 2012 Olympics and the Gentrification of East London," City 17(1) (2013), 107-8.

43 "Newham Census Demographics United Kingdom," Qpzm LocalStats UK (2015), accessed March 9, 2015, http://localstats.co.uk/census-demographics/england/ london/newham.

44 Huw Thomas, Race and Planning: The UK Experience (London: UCL Press, 2000). Yasminah Beebeejaun, "Including the Excluded? Changing the Understandings of Ethnicity in Contemporary English Planning," Planning Theory and Practice 13(4) (2012): 529.

45 See following link for details of CARP's activities, accessed September 19, 2014, https://savecarpenters.wordpress.com.

46 Jasmin Stone, "Why I'm Occupying a Boarded-up East London Council House," Guardian (2014), accessed September 23, 2014, http://www.theguardian.com/ commentisfree/2014/sep/23/why-occupying-boarded-up-east-london-councilhouse-social-housing.

47 Andrea Klettner, "UCL Scraps Plans for $£ 1$ bn Campus at Carpenters Estate,” BD Online (2013), accessed February 22, 2015, http://www.bdonline.co.uk/ucl-scrapsplans-for- $\%$ C2\%A31 bn-campus-at-carpenters-estate/5054347.article.

48 Comment taken from an interview conducted with a policy adviser within the decentralization and neighbourhood planning team within the DCLG.

49 See the London Assembly Housing Committee report Knock it Down or Do It Up: The Challenge of Estate Regeneration (London: Greater London Authority, 2015), which notes that the regeneration of fifty London housing estates over the last decade has resulted in the net loss of more than 8,000 social homes.

50 LLDC, Local Plan, 200.

51 Ibid. 44.

52 Ibid. 41-66.

53 Ibid. 206.

\section{Bibliography}

Allmendinger, Phil, and Graham Haughton. "Post-Political Spatial Planning in England: A Crisis of Consensus?" Transactions of the Institute of British Geographers 37(1) (2012): 89-103. 


\section{Amps}

Allmendinger, Phil, and Graham Haughton. "Post-Political Regimes in English Planning: From Third Way to Big Society." In Planning Against the Political: Democratic Deficits in European Territorial Governance, edited by Jonathan Metzger, Phil Allmendinger, and Stijn Oosterlynck, 29-54. Abingdon: Routledge, 2015.

Beebeejaun, Yasminah. "Including the Excluded? Changing the Understandings of Ethnicity in Contemporary English Planning." Planning Theory and Practice 13(4) (2012): 529-48.

Brownill, Sue, and Gavin Parker. "Why Bother with Good Works? The Relevance of Public Participation(s) in Planning in a Post-Collaborative Era." Planning Practice and Research 25(3) (2010): 275-82.

Cooke, Bill, and Uma Kothari "The Case for Participation as Tyranny." In Participation the New Tyranny, edited by Bill Cooke and Uma Kothari, 1-15. London and New York: Zed Books, 2001.

Council on Tribunals, Public Participation in Planning - The Skeffington Report: "People and Planning" (1969), BL 7/9, The National Archives, London.

Department for Communities and Local Government. "Plain English Guide to the Planning System." 2011. Accessed February 11, 2015. https://www.gov.uk/ government/uploads/system/uploads/attachment_data/file/5959/1896534.pdf.

Department for Communities and Local Government. "Plain English Guide to the Planning System." 2015. Accessed February 11, 2015. https://www.gov.uk/ government/publications/plain-english-guide-to-the-planning-system.

Damer, Seán, and Cliff Hague, "Public Participation in Planning: A Review." The Town Planning Review 42(3) (1971): 217-32.

Durose, Catherine, and Vivien Lowndes. "Neighbourhood Governance: Contested Rationales within a Multi-Level Setting - A Study of Manchester." Local Government Studies 36(3) (2010): 341-59.

Gallent, Nick, and Steve Robinson. Neighbourhood Planning: Communities, Networks and Governance. Bristol: Policy Press, 2012.

Greater London Authority. "Draft Further Alterations to the London Plan: The Spatial Development Strategy for Greater London.” 2014. Accessed July 1, 2014. https://www.london.gov.uk/sites/default/files/FALP.pdf.

Haughton, Graham, and Phil Allmendinger. "Moving On - From Spatial Planning to Localism and Beyond." Town and Country Planning 80(4) (2011): 184-7.

Healey, Patsy. Collaborative Planning: Shaping Places in Fragmented Societies, 2nd edition. Basingstoke: Palgrave, Macmillan, 2006.

Klettner, Andrea. "UCL Scraps Plans for $£ 1$ bn Campus at Carpenters Estate.” BD Online, 2013. Accessed February 22, 2015. http://www.bdonline.co.uk/ucl-scrapsplans-for- $\%$ C2\%A31bn-campus-at-carpenters-estate/5054347.article.

Locality. "The Power of Neighbourhood Planning." 2014. Accessed February 10, 2015. http://mycommunityrights.org.uk/wp-content/uploads/2014/12/The-Powerof-NP1.pdf.

London Assembly Housing Committee. Knock it Down or Do it Up: The Challenge of Estate Regeneration. London: Greater London Authority, 2015.

London Communications Agency. "London Neighbourhood Forums June 2015." 


\section{Amps}

2011. Accessed September 11, 2015. http://londonfirst.co.uk/wp-content/uploads/ 2015/05/lnd_neighbourhood_forums_v3.15.05.19.pdf.

London Legacy Development Corporation. "Local Plan Publication Stage Archive." 2015. Accessed February 15, 2015. http://queenelizabetholympicpark.co.uk/ our-story/transforming-east-london/local-plan/local-plan-publication-stagearchive.

London Legacy Development Corporation. Local Plan 2015 to 2031. London: London Legacy Development Corporation, 2015.

London Legacy Development Corporation. "Planning Area Map." 2015. Accessed February 2, 2015. http://queenelizabetholympicpark.co.uk/planning-authority/ planning-area-map.

Ministry of Housing and Local Government, People and Planning: Report of the Committee on Public Participation in Planning. 1969. CAB 151/65, London, The National Archives, 1969.

Mouffe, Chantal. On the Political: Thinking in Action. London and New York: Routledge, 2005.

Parker, Gavin. "Neighbourhood Planning: Precursors, Lessons and Prospects.” Paper presented at the 40th Joint Planning Law Conference, Oxford, September 14-16, 2012.

Peterman, William. Neighbourhood Planning and Community-Based Development: The Potential and Limits of Grassroots Action. Thousand Oaks, CA: SAGE, 2000.

Planning Advisory Group. The Future of Development Plans, Report of the Planning Advisory Group (PAG). London: HMSO, 1965.

Pratt, John, and Rebecca Fearnley. "Stratford City Challenge." In Rising East: The Regeneration of East London, edited by Tim Butler and Michael Rustin, 327-52. London: Lawrence \& Wishart, 1996.

Qpzm. "Newham Census Demographics United Kingdom.” Qpzm LocalStats UK (2015). Accessed March 9, 2015. http://localstats.co.uk/census-demographics/ england/london/newham.

Raco, Mike, and Wen-I Lin. "Urban Sustainability, Conflict Management, and the Geographies of Postpoliticism: A Case Study of Taipei." Environment and Planning C: Government and Policy 30(2) (2012): 191-208.

Raco, Mike, Gavin Parker, and Joe Doak. "Reshaping Spaces of Local Governance? Community Strategies and the Modernisation of Local Government in England." Environment and Planning C: Government and Policy 2(4) (2006): 475-96.

Rancière, Jacques. Disagreement: Politics and Philosophy. Minneapolis, MN: University of Minnesota Press, 1999.

Rancière, Jacques. "Ten Theses on Politics." Theory and Event 5(3) (2001). Accessed September 24, 2014. http://muse.jhu.edu/journals/theory_and_event/ v005/5.3ranciere.html.

Roy, Ananya. "Urban Informality: Toward an Epistemology of Planning." Journal of the American Planning Association 71(2) (2005): 147-58.

Stone, Jasmin. "Why I'm Occupying a Boarded-up East London Council House." Guardian, September 23, 2014. http://www.theguardian.com/commentisfree/2014/ sep/23/why-occupying-boarded-up-east-london-council-house-social-housing. 


\section{Amps}

Swyngedouw, Erik. "The Antinomies of the Postpolitical City: In Search of a Democratic Politics of Environmental Production." International Journal of Urban and Regional Research 33(3) (2009): 601-20.

Tewdwr-Jones, Mark, Morphet, Janice, and Philip Allmendinger. "The Contested Strategies of Local Governance: Community Strategies, Development Plans, and Local Government Modernisation.” Environment and Planning A 38(3) (2006): 533-51.

Thomas, Huw. Race and Planning: The UK Experience. London: UCL Press, 2000.

Watt, Paul. "'It's not for us': Regeneration, the 2012 Olympics and the Gentrification of East London." City 17(1) (2013): 99-118. 